\title{
LITERASI TEKNOLOGI INFORMASI DAN KOMUNIKASI
}

\author{
Syarifuddin \\ Balai Besar Pengkajian dan Pengembangan Komunikasi dan Informatika (BBPPKI) Makassar, JL. Prof. \\ Abdurrahman Basalamah II No. 25 Makassar. Tlp. 0411-4660084 \\ HP.0811446235.Email:syarif_akbar@ymail.com. \\ Naskah dikirim tanggal 29 Agustus 2014., direvisi tanggal 3 November 2014, disetujui tanggal 26 November 2014
}

\section{INFORMATION AND COMMUNICATIONS TECHNOLOGY LITERACY}

\begin{abstract}
Development of information and communication technology (ICT) has brought changes for the people of Indonesia. With ICT, community can easily access a variety of information and support jobs. But the problem that arises is the uneven penetration of ICT in all parts of Indonesia, including in South Sulawesi. Giving rise to the digital divide as well as the weakness of ICT literacy. Therefore, this study aims to determine the ICT literacy community in South Sulawesi. The method used in this study is a survey with a quantitative approach. The results show that ICT (computer, mobile phone, and internet) has been used by communities in South Sulawesi. Among the three media, mobile phone has the highest number of penetration followed by computer and the internet. The majority of respondents have also entered into 5 levels of ICT literacy mobile phones and computers as an integral part of daily activities. While the internet was still in level 3 where they have been used but not significantly.
\end{abstract}

Keywords: literacy, information communication technology, mobile phones, computers, internet.

\begin{abstract}
Abstrak
Perkembangan teknologi informasi dan komunikasi (TIK) telah membawa perubahan bagi masyarakat Indonesia. Dengan TIK masyarakat lebih mudah mengakses berbagai informasi dan menunjang pekerjaan. Namun masalah yang timbul yaitu penetrasi TIK yang tidak merata di seluruh wilayah Indonesia termasuk di Sulawesi Selatan. Sehingga menimbulkan kesenjangan digital dan juga lemahnya literasi TIK. Penelitian ini bertujuan untuk mengetahui literasi TIK masyarakat di Sulawesi Selatan. Metode penelitian yang digunakan dalam penelitian ini adalah survei dengan pendekatan kuantitatif. Hasil penelitian menunjukkan bahwa TIK (komputer, internet, telepon selular) telah digunakan oleh masyarakat di Sulawesi Selatan. Untuk ketiga media tersebut, penetrasi telepon seluler yang paling tinggi menyusul komputer dan internet. Mayoritas responden juga telah masuk ke tingkat lima literasi TIK, telepon seluler, dan komputer sebagai bagian yang tidak terpisahkan dari aktivitas sehari-hari. Sedangkan untuk internet masih berada di tingkat tiga di mana mereka telah menggunakannya, namun tidak secara signifikan..
\end{abstract}

Kata kunci: literasi, teknologi informasi komunikasi, telepon seluler, komputer, internet.

\section{PENDAHULUAN}

Ketika informasi telah menjadi suatu komoditas penting dalam kehidupan manusia, itu menunjukkan bahwa masyarakat telah masuk ke dalam satu era baru, yakni era masyarakat infomasi, era di mana masyarakat tidak lagi mau ketinggalan informasi, sehingga masyarakat dianggap aktif dalam menggunakan media untuk suatu tujuan 
tertentu. Perubahan ini, tentu saja, didorong oleh perkembangan teknologi komunikasi yang membuat arus informasi sedemikian cepat, hingga jarak tidak lagi membatasi transfer informasi.

Kehadiran TIK (internet) misalnya dalam perkembangan selama ini, telah membawa perubahan bagi masyarakat. Hanya saja, kesenjangan digital khususnya di negara-negara berkembang seperti Indonesia masih menjadi masalah yang harus dipecahkan. Salah satu faktor yang memengaruhi kesenjangan digital, termasuk ICT literacy, adalah faktor sosial ekonomi dan geografis. Sebagaimana hasil penelitian Mohd bin Zakariya (Hoesin, dkk, 2009) di beberapa kawasan Malaysia. Kedua faktor tersebut sangat berpengaruh dalam memeroleh kesempatan penggunaan komputer dan mengakses internet. Hasil riset ini juga menunjukkan bahwa penggunaan komputer dan intemet mampu meningkatkan pengetahuan dan keterampilan responden.

Tapscott dalam Indrajit, dkk (2006) berpendapat bahwa siklus evolusi e-literacy di dalam masyarakat berbeda-beda pada setiap kelompok generasi. Pada old generation yang diistilahkan sebagai generasi baby boomers, biasanya kelompok ini mengawali proses evolusi e-literacy dengan kompetensi information literacy yang telah dikuasai terlebih dahulu. Kategori kedua, new generation, ialah mereka yang pada tahun 2002 sudah dikenalkan komputer sejak usia dini. Kategori ketiga ialah today generation, yaitu para remaja dan pemuda saat ini, yang secara kategori generasi berada pada dua titik ekstrem tersebut.

Sekitar 58,7\% dari penduduk Indonesia saat ini berdiam di wilayah perdesaan (Biro Pusat Statistik, 2006). Persoalan yang dihadapi oleh penduduk yang tinggal di perdesaan, pada umumnya adalah rendahnya tingkat pendidikan, rendahnya akses informasi, dan lemahnya tingkat ekonomi masyarakat. Kondisi demikian merupakan sebab-akibat di antara ketiganya, artinya tingkat pendidikan yang rendah dapat berakibat atas rendahnya akses informasi, tingkat ekonomi yang rendah berakibat terhadap rendahnya tingkat pendidikan, dan rendahnya tingkat akses informasi dapat pula mengakibatkan rendahnya tingkat ekonomi.

Berdasarkan uraian di atas, maka permasalahan pokok yang akan ditelusuri dalam penelitian ini adalah sejauhmana literasi teknologi informasi dan komunikasi masyarakat di Sulawesi Selatan. Tujuan dari penelitian ini adalah untuk mengetahui literasi teknologi informasi dan komunikasi masyarakat di Sulawesi Selatan.

\section{LANDASAN KONSEP}

\section{Literacy Teknologi Informasi dan Komunikasi}

Literasi media adalah kemampuan yang efektif dan efisien untuk memahami dan pemanfaatan konten media massa atau the ability to effectively and efficiently comprehend and utilize mass media content (Baran, dkk., 2010). Selanjutnya, Hobbs (1998) mengungkapkan bahwa tujuan dari media literacy, antara lain: (1) Penguatan akses terhadap informasi; (2) Mendukung dan menumbuhkembangkan lingkungan pendidikan; (3) Menginspirasikan untuk mengembangkan akses terhadap berbagai sumber informasi.

Baran, dkk (2006) mengemukakan beberapa elemen dari media literasi, di antaranya, adalah: (1) An awereness of the impact of media (kesadaran atas dampak media pada individu); (2) An understanding of the process of mass communication (pemahaman pada proses komunikasi massa); (3) Strategies of analyzing and discussing media massages (pengembangan strategi yang digunakan untuk menganalisis dan mendiskusikan pesan-pesan media); (4) $A n$ understanding of media content as a text that provides insight into our culture and our lives (pemahaman pada konten media sebagai sebuah teks yang memberi wawasan pada kultur dan kehidupan manusia); (5) The ability to enjoy, understand, and appreciate media content (kemampuan untuk menikmati, memahami dan mengapresiasi konten media); (6) An understanding of the ethical and moral obligations of media practitioners (memahami tuntutan etika dan moral dari 
para praktisi media); (7) Development of appropriate and effective production skills (mengembangkan kemampuan-kemampuan produksi secara memadai dan efektif).

Salah satu model untuk mengukur tingkat literacy TIK di masyarakat biasanya digunakan Personal Capability Matuarity Model (P-CMM). Dalam hal ini literacy TIK dikategorikan atas lima tingkatan, yaitu: Tingkat nol $=$ jika seorang individu sama sekali tidak tahu dan tidak peduli akan pentingnya informasi dan teknologi untuk kehidupan sehari-hari. Tingkat satu $=$ jika seorang individu pernah memiliki pengalaman satu dua kali, di mana informasi merupakan sebuah komponen penting untuk pencapaian keinginan dan pemecahan masalah, dan telah melibatkan teknologi informasi untuk mencarinya. Tingkat dua $=$ jika seorang individu telah berkali-kali menggunakan teknologi untuk membantu aktivitas sehari-hari dan telah memiliki pola keberulangan dalam penggunaannya. Tingkat tiga $=$ jika seorang individu telah memiliki standar penguasaan dan pemahaman terhadap informasi maupun teknologi yang diberlakukannya dan secara konsisten memergunakan standar tersebut sebagai acuan penyelenggaraan aktivitas sehari-hari. Tingkat empat $=$ jika seorang individu telah sanggup meningkatkan secara signifikan (dapat dinyatakan kuantitatif) kinerja aktivitas kehidupan sehari-harinya melalui pemanfaatan informasi dan teknologi. Tingkat lima $=$ jika seorang individu telah menganggap informasi dan teknologi sebagai bagian yang tidak terpisahkan dari aktivitas sehari-hari dan secara langsung maupun tidak langsung telah mewarnai perilaku dan budaya hidupnya (Badan Litbang SDM Kominfo, 2013).

Untuk memahami literasi masyarakat terhadap TIK harus diketahui dulu berbagai elemen dari pengetahuan, pengalaman literasi, serta kemampuan lainnya yang harus dimiliki masyarakat. Untuk mengukur tingkat literasi masyarakat terhadap teknologi informasi dan komunikasi, tentunya dapat dilakukan dari tingkat pengenalan, penggunaan, dan tujuan menggunakan teknologi informasi dan komunikasi (TIK) beserta berbagai elemennya.

Penelitian ini akan melihat tingkat literasi TIK dalam hal ini komputer, internet, dan telepon seluler. Adapun literasi yang digunakan adalah pemanfaatan ketiga media tersebut oleh responden, lokasi yang sering digunakan saat pemanfaatan dan frekuensi menggunakan media TIK tersebut. Tingkat pemahaman literasi TIK diukur dengan menggunakan Personal Capability Matuarity Model (P-CMM). Dari sini dapat dilihat literasi TIK responden berada pada tahapan berapa.

\section{METODE PENELITIAN}

Penelitian ini menggunakan metode penelitian survei dengan pendekatan kuantitatif. Pengumpulan data dilakukan melalui survei di Provinsi Sulawesi Selatan, dengan mengambil empat sampel wilayah kabupaten/kota, yaitu Makassar, Bantaeng Palopo, dan Barru. Prinsip pemilihan lokasi penelitian didasarkan pada dua pertimbangan, pertama, pertimbangan representasi lokasi

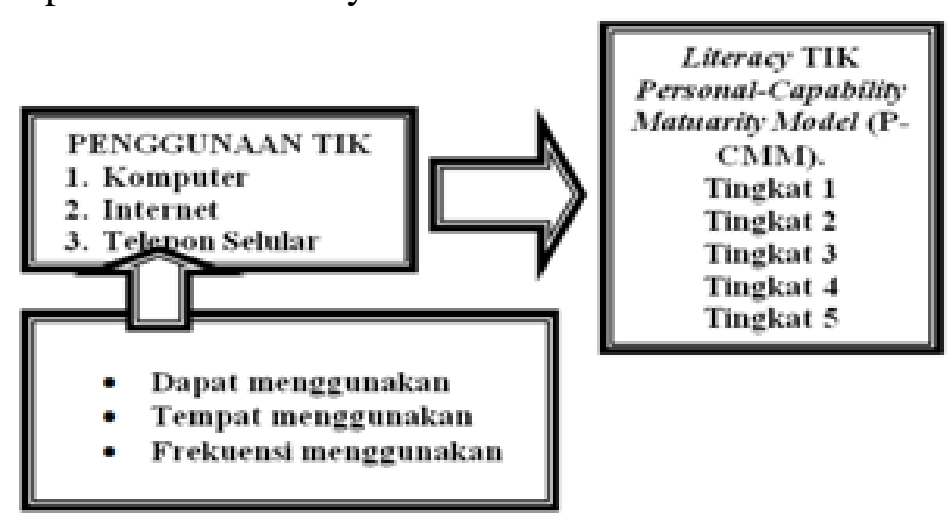

Gambar 1

Kerangka Konsep 
dan populasi. Kedua, pertimbangan efektivitas pelaksanaan penelitian. Terkait dengan pertimbangan tersebut, maka sistematika pemilihan lokasi penelitian ini disusun seperti pada tabel 1 .

Guna menghasilkan sampel yang dapat merepresentasikan populasi di seluruh lokasi penelitian, maka teknik pengambilan sampel memakai metode multistage random sampling. Penentuan besaran sampel dari populasi tersebut ditetapkan dengan menggunakan rumus Slovin (Bungin, 2006) yaitu:

$$
n=\frac{N}{1+N e^{2}}=625 \text { responden }
$$

Sementara media TIK yang dibahas dalam penelitian ini dibatasi tiga produk TIK yaitu komputer, internet, dan telepon selular. Pemilihan media ini adalah sebagai media yang paling familier dan banyak digunakan di masyarakat umum. Untuk mendapatkan validitas dan reliabilitas instrumen yang digunakan, terlebih dahulu dilakukan uji coba (pre test), untuk memastikan apakah instrumen tersebut merupakan alat ukur yang akurat dan dapat dipercaya. Validitas menunjukkan sejauhmana suatu alat pengukur itu mengukur apa yang ingin diukur. Sedangkan reliabilitas menunjukkan sejauh mana suatu hasil pengukuran relatif konsisten apabila pengukuran terhadap aspek yang sama pada alat ukur yang sama atau disebut juga internal consistency reliability (Singarimbun dan Effendy, 1995).
Pengolahan data dan analisis data dilakukan melalui beberapa langkah, yaitu mengedit, mengoding serta tabulasi (data entry), dan validasi data. Data yang sudah dientry kemudian dianalisis menggunakan teknik statistik deskriptif dan asosiatif/korelasional untuk data yang memenuhi persyaratan.

\section{HASIL PENELITIAN DAN PEMBAHASAN}

Penelitian ini mengambil 625 responden sebagai sampel. Adapun identitas responden hasil penelitian menunjukkan responden jenis kelamin, laki-laki yang paling dominan dalam penelitian ini, yaitu sebanyak 348 responden $(55,7 \%)$ menyusul perempuan sebanyak 277 responden atau (44,3\%). Sementara usia responden terbanyak antara 17 hingga 21 tahun yaitu sebanyak 103 responden $(16,5 \%)$ dan yang paling sedikit adalah responden dengan usia 52-56 tahun dan 57-60 tahun masing-masing $6,2 \%$.

Hasil ini menunjukkan bahwa laki-laki cenderung lebih menguasai perangkat TIK dibanding perempuan. Ini terlihat dari hasil penelitian di mana laki-laki kebanyakan yang memiliki akses terhadap TIK. Di samping itu usia responden yang mayoritas masih muda yaitu antara 17 hingga 21 menunjukkan bahwa penetrasi TIK lebih cepat merambah di kalangan anak muda dibanding orang yang lebih dewasa. Hal ini menunjukkan anak muda lebih mudah mengakses TIK.

Tabel 1

Jumlah Penduduk Kota Lokasi Penelitian

\begin{tabular}{clc}
\hline No & Lokasi Penelitian (Poropinsi/Kota) & $\begin{array}{c}\text { Jumlah } \\
\text { populasi }\end{array}$ \\
\hline 1. & Makassar & 1.253 .656 \\
2. & Bantaeng & 172.849 \\
3. & Palopo & 141.996 \\
4. & Barru & 161.732 \\
\hline & Jumlah Total & 1.730 .233 \\
\hline
\end{tabular}

Sumber: Sulawesi Selatan dalam Angka, 2010. 


\section{Penggunaan Komputer}

Bagian ini merupakan analisis pemanfaatan/penggunaan komputer oleh responden. Mayoritas responden yaitu 358 reponden $(57,28 \%)$ bisa memanfaatkan komputer, sedangkan 267 responden $(42,72 \%)$ menyatakan tidak bisa memanfaatkan komputer. Hal ini tergambar pada usia responden dan tentu juga terkait dengan pendidikan responden, usia muda, dan berpendidikan cenderung menggunakan dan memanfaatkan komputer sebagai kebutuhan dan kaitannya dengan pelajaran.

Dalam penelitian ini hanya 358 responden saja yang akan dijadikan objek yang berkaitan dengan penggunaan komputer. Dari 358 responden, sebanyak 334 responden $(53,44 \%)$ menyatakan menggunakan komputer dalam satu bulan terakhir. Sedangkan sebanyak 21 responden $(3,36 \%)$ menyatakan tidak pernah memanfaatkan komputer selama satu bulan terakhir, sementara tiga orang $(0,48 \%)$ tidak menjawab. Oleh karena itu dapat dikatakan bahwa komputer menjadi hal yang penting bagi responden karena hanya sekitar 24 responden $(3,84 \%)$ yang tidak menyatakan menggunakan dalam sebulan terakhir.

Untuk frekuensi tingkat penggunaan komputer dalam seminggu, sebanyak 102 responden $(28,49 \%)$ menyatakan menggunakan komputer lima kali dalam seminggu. Sementara frekuensi yang paling minim adalah enam kali dalam seminggu yaitu hanya empat responden (1,68\%). Dengan demikian maka responden yang menggunakan/memanfaatkan secara aktif komputer sebanyak 108 responden $(30,7 \%)$ dari totalitas 334 responden yang menggunakan komputer pada satu bulan terakhir (lihat grafik 1).

Tempat responden menggunakan komputer yang paling banyak adalah di rumah sendiri yaitu sebanyak 186 responden $(29,76 \%)$. Menyusul di tempat kerja, 160 responden $(25,60 \%)$, kampus 71 responden $(11,36 \%)$ dan di tempat kursus enam responden $(0,96 \%)$.

Tujuan responden menggunakan komputer adalah untuk mengolah kata, mengolah data, dan mengolah angka, hal ini merupakan tujuan yang paling dominan yaitu 282 responden selebihnya adalah bermain game, multimedia (video, musik, dan lainlain), desain grafis. Data secara lengkap terlihat pada grafik 4 .

Sementara itu sebanyak 164 reponden $(26,24 \%)$ mengaku menghabiskan waktu kurang dari dua jam sehari untuk bersenangsenang dengan menggunakan komputer. Sedang yang paling sedikit adalah enam responden $(0,96 \%)$ yang menggunakan komputer untuk bersenang-senang lebih dari delapan jam sehari.

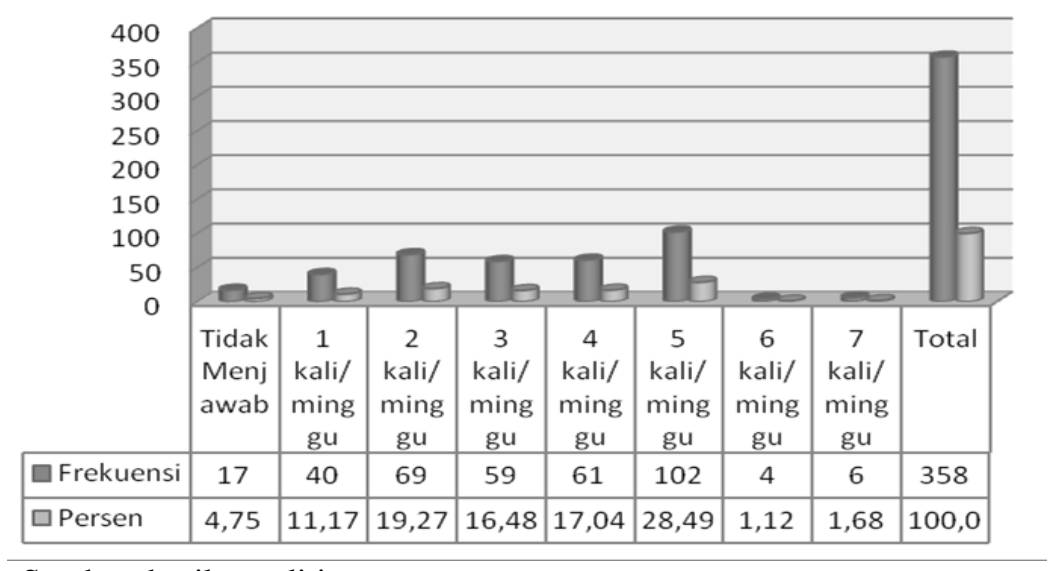

Sumber: hasil penelitian.

Grafik 1

Tingkat Penggunaan Komputer dalam Seminggu 


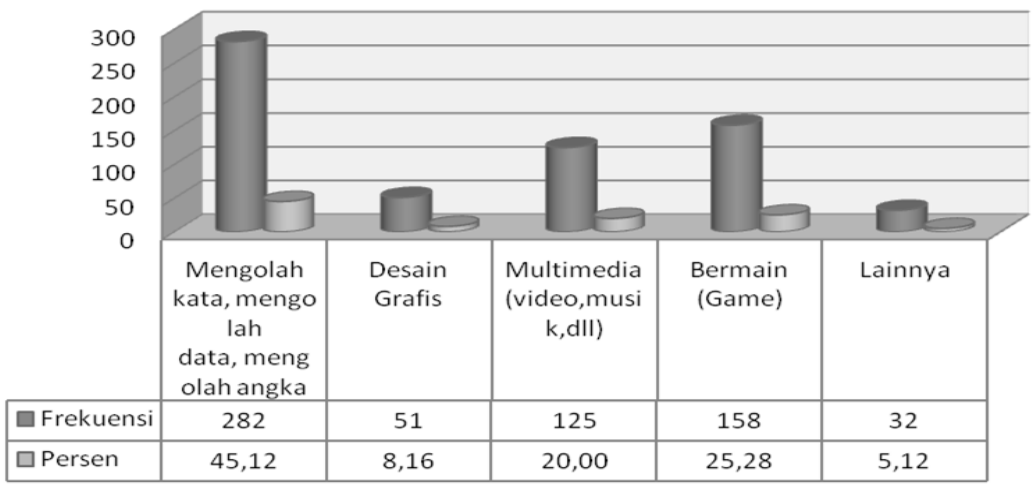

Sumber: hasil penelitian.

Grafik 2

Tujuan Penggunaan Komputer

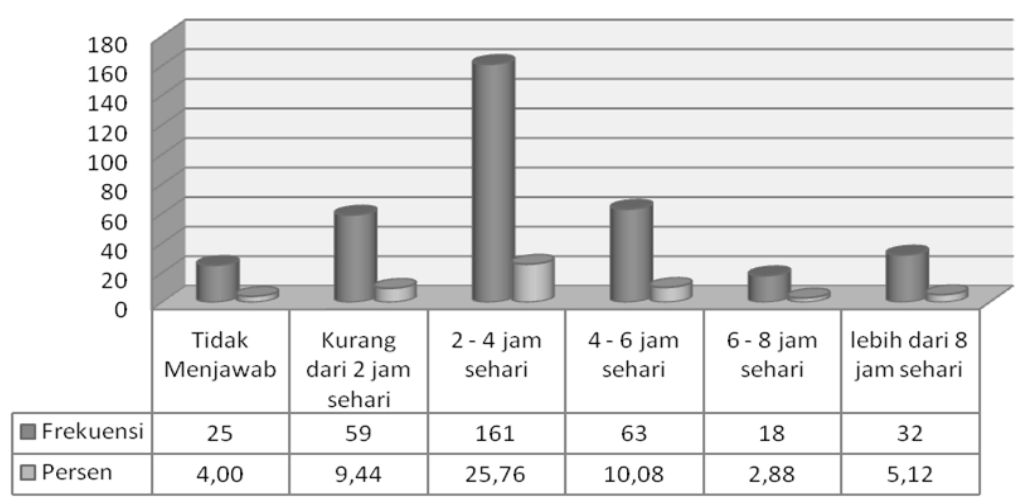

Sumber: hasil penelitian.

\section{Grafik 3}

\section{Penggunakan Komputer untuk Bekerja}

Pada grafik 3 tampak bahwa maksimal responden (161 responden atau 25,76\%) menghabiskan waktu dua sampai empat jam dalam sehari dalam menggunakan pekerjaan untuk bekerja. Sedangkan hanya 32 responden $(5,12 \%)$ menggunakan komputer selama enam samapi delapan jam sehari dalam bekerja.

Hasil penelitian mengenai peran komputer dalam membantu pekerjaan mereka. 192 responden $(30,72 \%)$ mengaku bahwa komputer sangat membantu mereka dalam melaksanakan pekerjaan. Hanya satu responden $(0,16 \%)$ yang menjawab bahwa komputer tidak membantu pekerjaannya.

\section{Penggunaan Internet}

Bagian ini akan membahas masalah penggunaan internet oleh responden. Grafik 4 menunjukkan bahwa, responden yang paling banyak menyatakan, telah menggunakan internet dan hanya sebagian kecil saja yang menyatakan tidak menggunakan internet. Ini berarti responden memang sudah memanfaatkan internet dalam kehidupan mereka sehari-hari.

Sedangkan untuk pemanfaatan internet, hasil penelitian menunjukkan bahwa, dari 295 responden yang memanfaatkan internet, 279 responden $(44,64 \%)$ di antaranya yang menyatakan pernah menggunakan internet dalam satu minggu terakhir ini. Sedangkan 16 responden $(2,56 \%)$ menyatakan tidak menggunakan internet dalam seminggu ini.

Selanjutnya adalah frekuensi yang paling dominan digunakan oleh responden dalam menggunakan internet adalah tiga kali dalam seminggu. Tercatat 60 responden $(9,60 \%)$ yang memilih jawaban tersebut. Sedangkan 15 responden $(2,40 \%)$ yang menyatakan menggunakan internet enam kali dalam seminggu. 


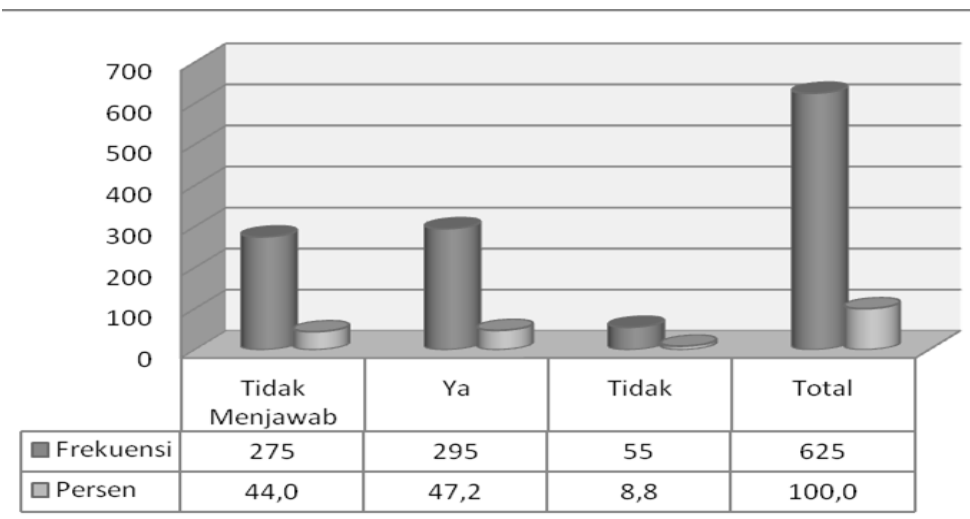

Sumber: hasil penelitian.

Grafik 4

Penggunaan Internet

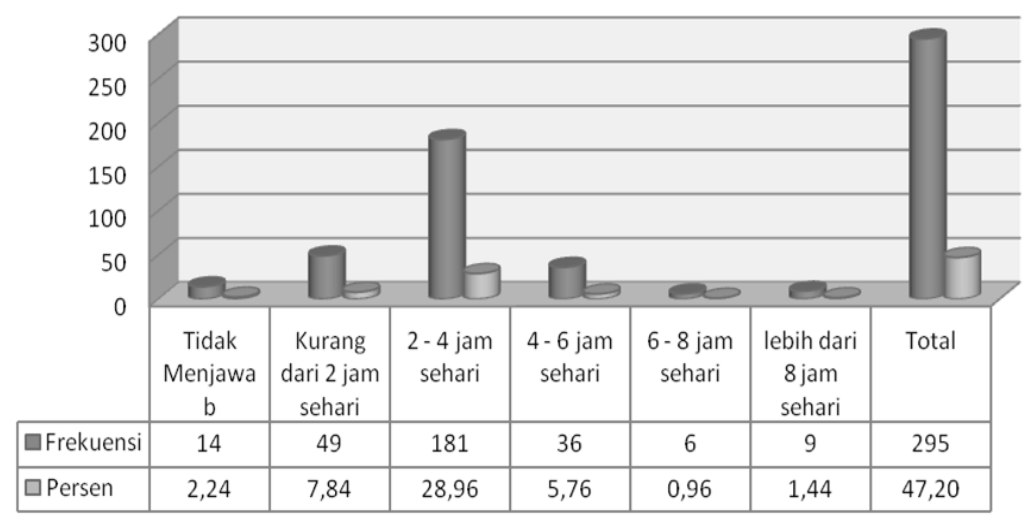

Sumber: hasil penelitian.

Grafik 5

Frekuensi Penggunaan Internet dalam Sehari

Tempat responden ketika mengakses atau menggunakan initernet berdasarkan hasil penelitian menunjukkan bahwa, paling banyak responden menggunakan internet di warung internet (warnet) yaitu 154 responden $(24,64 \%)$, menyusul di rumah sendiri sebanyak 118 responden $(18,88 \%)$, di tempat kerja, 98 responden $(15,68 \%)$, di kampus/sekolah/perpustakaan sebanyak 55 responden $(8,80 \%)$ dan menggunakan hotspot gratis sebanyak 50 responden $(8,00 \%)$. Warnet masih menjadi tempat favorit responden untuk mengakses internet, meskipun saat ini sudah banyak operatoroperator yang menawarkan paket-paket murah internet.

Kebanyakan responden yaitu 181 responden $(28,96 \%)$ dalam sehari menghabiskan dua sampai empat jam/hari saat menggunakan internet, dan hanya enam responden yang menggunakan enam sampai delapan jam sehari saat menggunakan internet (lihat Grafik 5).

Sementara itu fasilitas internet yang dimiliki oleh responden, berdasarkan hasil penelitian bahwa mayoritas responden memiliki alamat email (229 responden atau $36,64 \%$ ) kemudian diikuti dengan kepemilikan akun pribadi pada situs jejaring sosial seperti facebook, friendster, twitter, dan lain-lain sebanyak 219 responden $(35,04 \%)$, media chatting sebanyak 142 responden $(22,72 \%)$, kepemilikan blog sebanyak 43 responden $(6,88 \%)$ dan kepemilikan website sebanyak 40 responden $(6,40 \%)$.

Hasil penelitian menunjukkan bahwa tujuan penggunaan internet oleh responden didominasi untuk mengakses data dan 
informasi sebanyak 233 responden $(37,28 \%)$ kemudian 190 responden $(30,40 \%)$ untuk mengakses jejaring sosial (facebook, friendster, twitter, dan lain-lain), 167 responden $(26,71 \%)$ melakukan download, email digunakan oleh 157 responden (25,12\%), chatting dimanfaatkan oleh 139 responden $(22,24 \%)$, bermain (game) sebanyak 102 responden (16,32\%), belanja online dimanfaatkan oleh 10 responden $(1,60 \%)$ sedangkan lainnya sebanyak enam responden $(0,96 \%)$.

Oleh sejumlah responden internet juga dipakai untuk bersenang-senang atau bermain game. Hasil penelitian menunjukkan bahwa sebanyak 132 responden $(21,12 \%)$ menghabiskan kurang dari dua jam sehari untuk bersenang-senang (game) dan hanya sebagian kecil dari mereka (lima responden, 0,80\%) yang menggunakan waktu 6-8 jam sehari dan lebih dari delapan jam sehari melakukan hal yang sama, seperti data pada grafik 6.

Sedangkan penggunaan internet untuk menunjang pekerjaan hasil penelitian menunjukkan bahwa sebanyak 148 responden $(23,68 \%)$ menghabiskan waktu dua sampai empat jam sehari dalam memanfaatkan internet untuk bekerja. Sedangkan 13 responden $(2,08 \%)$ yang menghabiskan waktu mereka antara enam sampai delapan jam menggunakan internet untuk menunjang pekerjaan.

Responden juga mengeluarkan biaya untuk menggunakan internet. Hasil penelitian menunjukkan bahwa paling banyak responden $128(20,48 \%)$ mengeluarkan biaya kurang dari Rp50.000. Sedangkan biaya yang paling sedikit dikeluarkan yaitu di atas $\mathrm{Rp}$ 200.000 dinyatakan 13 responden $(2,08 \%)$, (lihat grafik 7).

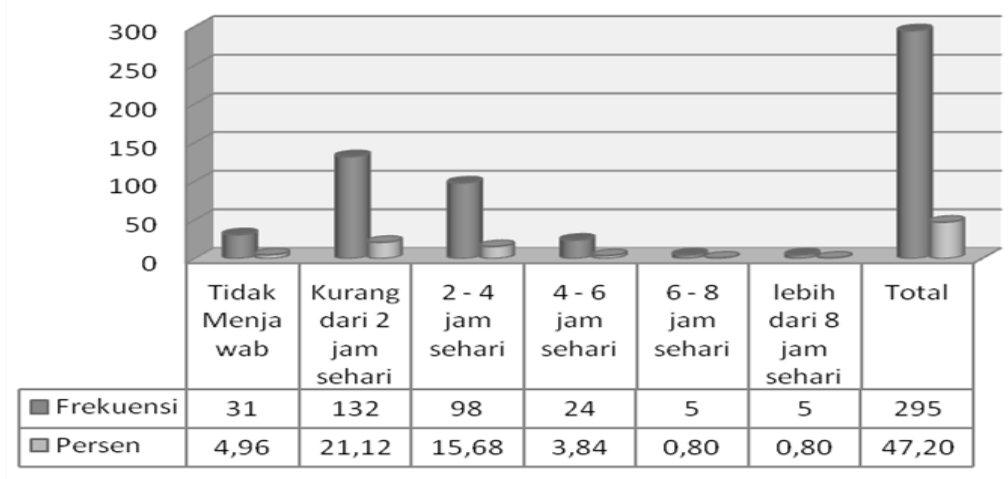

Sumber: hasil penelitian.

Grafik 6

Penggunaan Internet untuk Bersenang-Senang

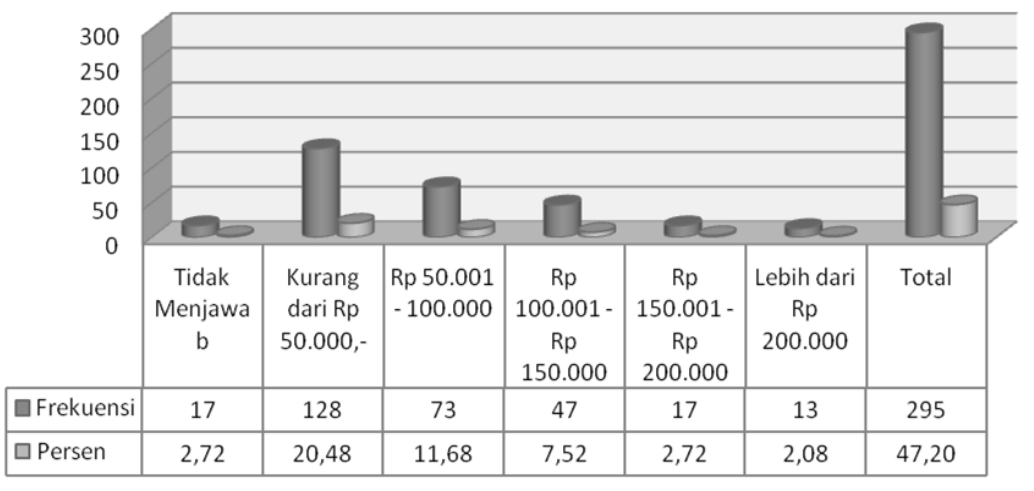

Sumber: hasil penelitian.

Grafik 7

Biaya penggunaan internet dalam sebulan 
Tidak dapat dipungkiri bahwa saat ini internet telah menjadi kebutuhan sehari-hari masyarakat. Mereka mengakui bahwa internet sangat bermanfaat baik untuk menunjang pekerjaan, pendidikan, dan lain-lain. Hasil penelitian menunjukkan bahwa, sebanyak 122 responden $(19,52 \%)$ menyatakan bahwa internet sangat membantu mereka dalam melaksanakan pekerjaan. Hanya empat responden $(0,64 \%)$ yang menyatakan bahwa internet tidak membantu pekerjaan mereka.

\section{Pengunaan Telepon Seluler}

Pada bagian ini akan dibahas tentang kepemilikan dan penggunaan telepon seluler/handphone. Telepon seluler/ handphone, yang merupakan produk dari teknologi komunikasi dan informasi, sudah tidak asing lagi bagi sebagian besar penduduk di Indonesia, bahkan alat komunikasi tersebut dapat dikatakan bukan menjadi barang mewah lagi. Jadi hampir dipastikan bahwa alat tersebut pasti menjadi barang yang wajib dimiliki. Hal tersebut dibuktikan dari hasil penelitian yang menunjukkan bahwa sebagian besar responden 539 responden $(86,24 \%)$ menyatakan memiliki telepon seluler, dan hanya 82 responden $(13,12 \%)$ yang menyatakan tidak memiliki telepon seluler sedangkan empat responden $(0,64 \%)$ tidak menjawab. Dengan demikian dapat disimpulkan bahwa telepon seluler sudah bukan menjadi barang yang mewah lagi karena sebagian besar responden sudah memiliki alat komunikasi tersebut.

Grafik 8 menunjukkan kepemilikan telepon seluler/handphone lebih dari satu, sebanyak 201 responden $(32,2 \%)$ memiliki lebih dari satu telepon seluler (minimal dua buah). Sehingga dapat disimpulkan bahwa dari 539 responden yang memiliki telepon seluler sebagian di antara mereka memiliki lebih dari dua telepon seluler.

Selama menggunakan telepon seluler, sebanyak 523 responden $(83,68 \%)$ memanfaatkannya untuk menelepon, menyusul SMS dimanfaatkan oleh 494 responden $(79,04 \%)$, kemudian fasilitas game dimanfaatkan oleh 163 responden $(26,08 \%)$, fasilitas internet dimanfaatkan oleh 128 responden (20,48\%), kemudian MMS sebanyak 75 responden (12\%) dan yang terakhir adalah fasilitas video call yang dimanfaatkan oleh 22 responden $(3,52 \%)$.

Penggunaan telepon seluler setiap hari tentu juga menggunakan biaya pulsa setiap bulannya. Sebagian besar responden atau 191 responden $(30,56 \%)$ menghabiskan biaya $\mathrm{Rp}$ 50.000 sampai Rp100.000 dalam sebulan untuk biaya pulsa, dan hanya 20 responden $(3,20 \%)$ yang menggunakan pulsa lebih dari Rp200.000 dalam sebulan.

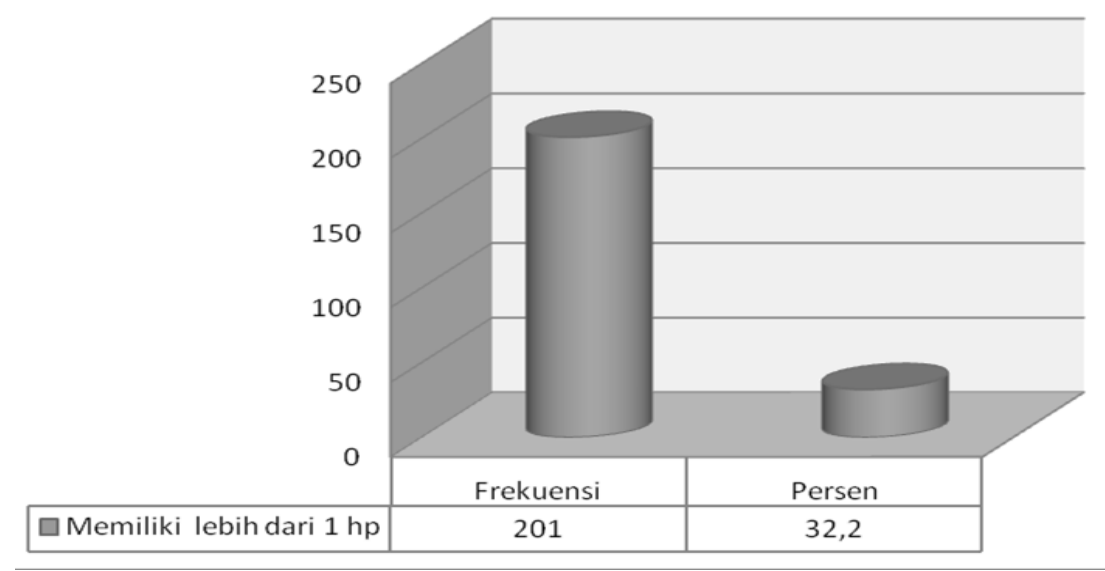

Sumber: hasil penelitian. 
Hasil temuan menunjukkan bahwa mayoritas responden berpendidikan terakhir SLTA dan S1. Pekerjaan terbanyak responden adalah Pegawai Negeri Sipil (PNS) dan pegawai swasta. Responden juga mayoritas terlibat dalam organisasi kemasyarakatan di luar tempat mereka bekerja yaitu di organisasi pemerintahan (non pemerintahan).

Dalam satu rumah responden rata-rata ada dua orang yang dapat menggunakan komputer. Pendapatan responden mayoritas berada dikisaran $<\mathrm{Rp} 1$ juta dan antara $\mathrm{Rp} 1$ juta-Rp 2 Juta. Mayoritas responden memiliki anggota keluarga yang tidak berpenghasilan sendiri, kalau pun ada hanya ada satu orang dalam satu rumah tangga. Sebagian besar responden juga setuju bahwa pemanfaatan teknologi informasi dan komunikasi (TIK) sangat menunjang pekerjaan mereka dan sangat membantu dalam menyelesaikan pekerjaan tersebut tepat waktu.

\section{Pembahasan}

Tingkat literasi teknologi informasi dan komunikasi (TIK) dalam penelitian ini yaitu alat yang digunakan oleh seseorang untuk berkomunikasi dan atau bertukar data dan informasi secara digital (online) meliputi komputer, internet, dan telepon seluler. Dari data yang diperoleh dapat disimpulkan bahwa pemanfaatan komputer sudah digunakan oleh mayoritas responden atau lebih dari 50\% responden menggunakan komputer paling banyak lima kali dalam seminggu selama dua sampai empat jam dalam sehari di rumah sendiri dan di tempat kerja. Tujuan responden menggunakan komputer mayoritas untuk mengolah data dan mengolah angka atau menyelesaikan pekerjaan di tempat kerja. Responden juga menggunakan komputer untuk bermain game (bersenang-senang) kurang dari dua jam dalam sehari.

Sebagian besar responden dalam penggunaan internet, juga sudah memanfaatkannya. Rata-rata tiga kali dalam seminggu mereka menggunakan internet di warnet dan di rumah sendiri selama dua sampai empat jam dalam sehari. Rata-rata responden memiliki email pribadi dan akun situs jejaring sosial. Tujuan menggunakan internet adalah untuk mengakses data dan informasi, membuka akun situs jejaring sosial, melalukan download, email, chatting, game dan belanja online. Internet juga dipakai responden untuk menyelesaikan pekerjaan di tempat kerja selama dua sampai empat jam dalam sehari. Responden juga memanfaatkan internet untuk bermain game online (bersenang-senang) kurang dari dua jam dalam sehari. Sementara biaya (pulsa dan warnet) yang digunakan oleh mayoritas responden adalah sekitar Rp50.000 sebulan untuk biaya pribadi karena kebanyakan dari responden menggunakan fasilitas internet dari tempat kerja secara gratis.

Telepon seluler /handphone sebagai salah satu teknologi informasi dan komunikasi yang paling banyak dimiliki oleh responden. Tercatat 539 responden yang menyatakan memiliki telepon selular, $201 \mathrm{di}$ antaranya memiliki telepon seluler lebih dari satu buah. Tujuan dari kepemilikan telepon seluler ini kebanyakan dipakai untuk menelepon, SMS, bermain game, internet, MMS, dan video call. Rata-rata responden juga mengeluarkan biaya Rp50.000 Rp100.000 untuk pemakaian pulsa.

Berdasarkanl analisis data penelitian di atas menunjukkan bahwa dalam perkembangan selama ini, kehadiran TIK khususnya komputer, internet, dan telepon seluler bukan lagi merupakan barang yang langka dan mahal, terutama untuk telepon seluler. Media ini dimiliki oleh hampir seluruh responden dalam penelitian ini bahkan sebagian di antaranya memiliki lebih dari satu telepon seluler.

Fenomena perkembangan TIK memang telah merambah ke seluruh pelosok kehidupan masyarakat dalam waktu cepat. Sehingga apa yang disampaikan Morgan Stanley bahwa penetrasi internet di masyarakat termasuk yang paling cepat dibandingkan media teknologi komunikasi dan informasi lainnya seperti radio dan televisi benar adanya.

Hasil penelitian ini juga menunjukkan bahwa masyarakat (responden) sudah masuk dalam kategori literasi TIK di mana mereka sebagai individu dalam menggunakan TIK mampu mengelola, mengatur, mengintegrasikan, dan mengevaluasi 
informasi, membangun pengetahuan baru dan berkomunikasi dengan orang lain sehingga dapat berpartisipasi secara efektif dalam masyarakat. Hasil penelitian ini juga merujuk bahwa perkembangan teknologi khususnya internet telah memberikan kontribusi yang demikian besar bagi penggunanya. Hadirnya internet telah menunjang efektivitas dan efisiensi pekerjaan juga sebagai sarana komunikasi, publikasi, serta informasi yang dibutuhkan oleh penggunanya (Rhodes, 1986).

Merujuk kepada teori PersonalCapabilty Maturity Model (P-CMM), hasil penelitian ini menunjukkan bahwa rata-rata literasi TIK responden terhadap media TIK telepon seluler/handphone dan komputer dapat dikategorikan pada tingkat lima, di mana mayoritas responden individu telah menganggap informasi dan teknologi sebagai bagian yang tidak terpisahkan dari aktivitas sehari-hari dan secara langsung maupun tidak langsung telah mewarnai perilaku dan budaya hidupnya atau bagian dari information society atau manusia berbudaya informasi. Ini terlihat dari $80 \%$ lebih responden beraktivitas sehari-hari dengan telepon seluler untuk menelepon/menerima telepon dan SMS. Sedangkan untuk literasi media TIK lainnya yaitu internet rata-rata responden masih berada pada tahap tiga yaitu responden telah memiliki standar penguasaan dan pemahaman terhadap informasi maupun teknologi yang diperlukannya, dan secara konsisten mempergunakan standar tersebut sebagai acuan penyelenggaraan aktivitas sehari-hari. Ini ditunjukkan bahwa responden telah memanfaatkan internet dalam kehidupan sehari-hari namun tidak signifikan dua media lainnya yaitu telepon seluler dan komputer.

\section{PENUTUP}

\section{Simpulan}

Literasi teknologi informasi dan komunikasi (TIK) masyarakat di Sulawesi Selatan sudah sangat memadai. Telepon selular merupakan media yang paling banyak digunakan oleh responden menysul komputer. Dan untuk pemanfaatan dua media ini, reponden mayoritas sudah sampai pada tahap lima, di mana mayoritas responden individu telah menganggap informasi dan teknologi sebagai bagian yang tidak terpisahkan dari aktivitas sehari-hari dan secara langsung maupun tidak langsung telah mewarnai perilaku dan budaya hidupnya atau bagian dari information society atau manusia berbudaya informasi.

Sedangkan untuk media internet, ratarata literasi media responden masih berada pada tahap tiga yaitu responden telah memiliki standar penguasaan dan pemahaman terhadap informasi maupun teknologi yang diperlukannya, dan secara konsisten mempergunakan standar tersebut sebagai acuan penyelenggaraan aktivitas sehari-hari. Ini ditunjukkan bahwa responden telah memanfaatkan internet dalam kehidupan sehari-hari namun tidak signifikan disebabkan keterbatasan infrastruktur dan jaringan yang masih kurang memadai di dua kabupaten. Namun hasil penelitian ini juga menyimpulkan bahwa ketergantungan masyarakat dalam menggunakan TIK sebagai media informasi.

\section{Saran}

Masih diperlukan pelibatan masyarakat TIK sebagai upaya peningkatan skill TIK masyarakat. Sebagai wilayah dengan kondisi masyarakat yang memunyai tingkat religi yang masih kuat maka perlu diarahkan untuk situs-situs yang positif dan dilakukan sosialisasi tentang bagaimana memanfaatkan TIK yang sehat dibanding hanya sekedar bermain game online.

\section{DAFTAR PUSTAKA}

\section{Buku:}

Badan Litbang SDM Kemkominfo. (2013). Dinamika Perkembangan Pemanfaatan TIK serta Implikasinya di Masyarakat. Jakarta: Media Bangsa.

Baran, S. dan Davis, D. (2010). Mass Communication Teory: Foundations, Frement and Future. (Terj. Alfrianto 
Daud dan Putri). Jakarta: Salemba Humanika.

Biro Pusat Statistik. (2006). Beberapa Indikator Penting Sosial Ekonomi Indonesia; Jakarta: Penerbit BPS; Edisi Juli.

Bungin, Burhan.(2006). Teknik Praktis Riset Komunikasi. Jakarta: Kencana Prenada Media Group.

Hoesin, Hanif dan Baso Saleh. 2009. Penggunaan Komputer dan Internet di Indonesia. Jurnal Pekomnas Penelitian Komunikasi dan Media Massa Makassar.. Vol.12, tahun 2009, hal 1529.

Indrajit R. dan Djokopranoto, R. (2006). Manajemen Perguruan Tinggi Modern.Yogyakarta: Penerbit ANDI.

Rhodes,I.K.(1993). Literacy Assesment. Heineman Educational Book.Inc.
Syamsuddin AAN, Munawar (2013), Metode Riset Kuantitatif Komunikasi, Pustaka Pelajar.

Singarimbun Masri dan Sofian Effendi. (1987). Metode Penelitian Survai,.Jakarta: LP3ES.

\section{Internet:}

Hobbs, R. (1998). Instructional Practices in Media Literacy and Their Impact on Students Learning. Tersedia dalam $<$ www.interact.uoregon.edu/MediaLit/r eadingarticles/hobbs/inspractice.html,> diakses 20 Agustus 2011.

Sulawesi Selatan dalam Angka. (2010). Tersedia dalam $<$ https://id.scribd.com/doc/122978569/s ulawesi-selatan-dalam-angka-2010,> diakses 20 Agustus 2011. 